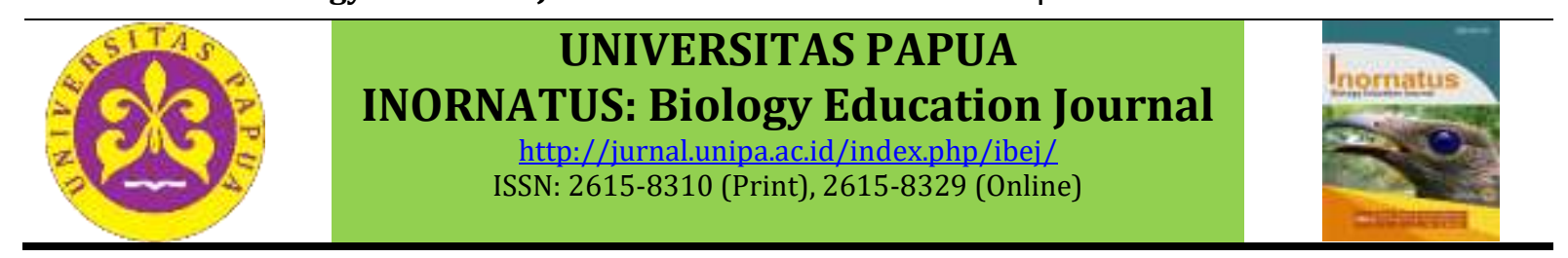

\title{
Standardization of science process skills (SPS) assessment instruments in microbiology labs
}

\section{Standarisasi instrumen penilaian keterampilan proses sains (KPS) pada praktikum mikrobiologi}

\author{
Nona Wingti Posangi*, Ani M. Hasan and Lilan Dama \\ Program Studi Pendidikan Biologi, Pasca Sarjana, Universitas Negeri Gorontalo \\ *korespondensi penulis : ing_posangi@ymail.com
}

\begin{abstract}
This study aims to standardize science process skills (SPS) instruments in microbiology labs. This Type research is quantitative descriptive, which focuses on standardizing instruments. The research subjects were students of the Biology Education Department of FMIPA Universitas Negeri Gorontalo who programed microbiology courses. Validation was carried out by three experts. The results showed that the value of validity was 4.95 in aspects of the assessment of items on SPS and 4.85 in aspects of language assessment. The results of measurements on science process skills of students have obtained an average of 3.00 in trials I and 3.37 in trial II. The reliability of the instrument in the first trial was 0.81 and in the second trial was 0.82 . The results of the research obtained indicate that KPS skill instruments are valid and reliable. The instrument can be used to measure student science process skills, especially in microbiology courses. Future research can compile PPP instruments in other subjects.
\end{abstract}

Keywords : Science process skills, validity, reliability, labs, micorbiology

\begin{abstract}
Abstrak
Penelitian ini bertujuan untuk membakukan instrumen keterampilan proses sains (KPS) pada praktikum mikrobiologi. Jenis penelitian adalah deskriptif kuantitatif, yang memfokuskan pada pembakuan instrument. Subjek penelitian adalah mahasiswa Jurusan Pendidikan Biologi FMIPA Universitas Negeri Gorontalo yang memprogramkan mata kuliah mikrobiologi. Validasi dilakukan oleh tiga orang ahli. Hasil penelitian menunjukkan bahwa nilai validitas sebesar 4.95 pada aspek penilaian butir soal KPS dan 4.85 pada aspek penilaian kebahasaan. Hasil pengukuran terhadap keterampilan proses sains mahasiswa diperoleh rata-rata 3,00 pada uji coba I dan 3,37 pada uji coba II. Reliabilitas instrumen pada uji coba I adalah 0,81 dan pada uji coba II adalah 0,82. Hasil penelitian yang diperoleh menunjukkan bahwa instrumen keterampilan KPS adalah valid dan reliabel. Instrumen dapat digunakan untuk mengukur keterampilan proses sains mahasiswa, khususnya pada mata kuliah mikrobiologi. Penelitian selanjutnya dapat menyusun instrumen KPS pada mata kuliah lainnya.
\end{abstract}

Kata kunci: Keterampilan proses sains, validitas, reliabilitas, praktikum, mikrobiologi

\section{Pendahuluan}

Undang Keterampilan proses sains dikatakan sebagai pendekatan yang bersifat generik. Keterampilan proses sains memiliki peran yang sangat penting dalam proses pembentukan ilmu pengetahuan yang dapat mempengaruhi perkembangan pengetahuan mahasiswa. Keterampilan proses sains (KPS) merupakan keterampilan yang dibutuhkan siswa saat mereka melakukan penyelidika (Damopolii dkk, 2018). Dengan mengembangkan keterampilan proses, mahasiswa akan mampu menemukan dan mengembangkan sendiri fakta, konsep, sikap dan nilai yang dituntut (Semiawan dkk, 1992), membentuk karakter siswa (Pujiastuti, 2012) 
dan dapat membentuk pola pikir secara ilmiah. Hal ini sesuai yang dikatakan oleh Rustaman (2003) bahwa pembelajaran biologi tidak hanya bertujuan untuk memahami pengetahuan, tetapi juga memberikan kesempatan kepada peserta didik agar terlibat dan belajar dengan menggunakan cara berpikir ilmiah.

Dengan demikian keterampilan proses sains dapat berimplikasi pada pengembangan kemampuan berpikir peserta didik. Semiawan dkk (1992) menyatakan bahwa keterampilan proses sains yang perlu dilatih dalam pembelajaran sains meliputi keterampilan mengamati, menghitung, mengukur, mengklasifikasi, mencari hubungan ruang/waktu, membuat hipotesis, merencanakan penelitian/percobaan, mengendalikan variabel, menafsirkan data, menyusun kesimpulan sementara, memprediksi/membuat hipotesis, menerapkan dan mengkomunikasikan data.

Keterampilan proses perlu dilatihkan atau dikembangkan dalam pembelajaran karena keterampilan proses mempunyai peran-peran sebagai berikut: membantu peserta didik mengembangkan pikirannya, memberi kesempatan kepada peserta didik untuk melakukan penemuan, meningkatkan daya ingat, membuat kepuasan intrinsik bila peserta didik berhasil melakukan sesuatu, membantu peserta didik mempelajari konsep-konsep sains (Dahar, 1985 dalam Devi, 2010). Keterampilan-keterampilan tersebut dapat dilatih melalui kegiatan praktikum.

Bersamaan dengan meningkatnya jenjang pendidikan, semestinya praktikum makin bersifat divergen dan lebih menantang, sesuai dengan meningkatnya kemampuan kognitif, pengetahuan dan keterampilan peserta praktikum. Menurut Damopolii, Hasan \& Kandowangko (2015) Praktikum merupakan kegiatan aplikasi dari teori-teori yang telah dipelajari untuk memecahkan berbagai masalah sains melalui eksperimen di laboratorium. Sebagaimana proses pembelajaran, kegiatan praktikum membutuhkan suatu alat ukur berupa instrumen penilaian. Keterkaitan pembelajaran dan penilaian tidak hanya melihat aspek produk tetapi pada segi keterampilan proses. Dengan adanya kegiatan praktikum dapat melatih kemampuan bereksperimen yang dapat merintis perkembangan sikap ilmiah dimana mahasiswa akan memiliki keterampilan proses. Oleh karena itu diperlukan penilaian terhadap kemampuan keterampilan proses yang dihasilkan.

Biologi sebagai salah satu cabang dari sains merupakan produk (berupa fakta, konsep, prinsip, hukum dan teori) dan sebagai proses (kerja ilmiah). Oleh karena itu, kegiatan praktikum dan penilaian harus memperhatikan biologi sebagai produk dan proses. Salah satu matakuliah yang dituntut adanya keterampilan dalam menguasai kerja laboratorium berupa metode eksperimen adalah Mikrobiologi. Mikrobiologi merupakan matakuliah wajib bagi mahasiswa jurusan pendidikan Biologi FMIPA UNG. Mikrobiologi ialah bidang ilmu yang menelaah mengenai organisme hidup yang berukuran mikroskopis (mikroorganisme). Pada matakuliah ini dituntut adanya keterampilan dalam menguasai kerja laboratorium berupa metode eksperimen atau praktikum. Hal ini disebabkan karena pembelajaran Mikrobiologi tidak lepas dari pembuktian teori-teori melalui kegiatan praktikum.

Pelaksanaan praktikum selain memuat konsep dasar Mikrobiologi dan keterampilan-keterampilan praktikum yang harus dimiliki mahasiswa, juga diberikan kemampuan untuk kerja ilmiah mulai dari menentukan masalah, mengembangkan 
hipotesis atau pertanyaan-pertanyaan, merancang percobaan, melakukan pengamatan untuk menjawab pertanyaan dan menarik kesimpulan. Keterampilanketerampilan ini akan berproses dalam kerja ilmiah. Selain itu, mahasiswa nantinya diharapkan mempunyai pengalaman belajar yang bermakna baik berupa bekal keterampilan, sikap, maupun nilai-nilai moral yang relevan dengan profesi yang akan diembannya.

Salah satu komponen penting dalam sistem pembelajaran adalah penilaian. Penilaian sebagai bagian internal dari proses pembelajaran hendaknya tidak dilakukan sesaat, tetapi harus dilakukan secara berkala, berkesinambungan dan menyeluruh. Menurut Suprananto (2012), penilaian adalah suatu prosedur sistematis dan mencaku kegiatan mengumpulkan, menganalisis, serta menginterpretasikan informasi yang dapat digunakan untuk membuat kesimpulan tentang karakteristik sesorang atau objek. Terkait dengan kegiatan pengukuran terhadap keterampilan proses sains mahasiswa, sangat diperlukan suatu instrumen yang teruji baik validitas maupun reliabialitasnya. Dalam kegiatan penelitian khususnya dalam bidang pendidikan, terdapat dua bentuk instrumen yang dapat digunakan yakni tes dan non tes (Hidayati \& Listyani, 2009).

Namun kenyataan yang terjadi belum sesuai yang diharapkan seperti yang diuraikan di atas. Selama ini, penilaian terhadap proses, laporan dan presentasi hasil kerja ilmiah mahasiswa sudah dilakukan, tetapi belum ada alat penilaian untuk menilai keterampilan proses mahasiswa. Disamping itu masih banyak mahasiswa yang kemampuan bereksperimen dan kerja ilmiahnya kurang maksimal, serta belum diterapkannya aspek keterampilan proses. Apabila hal ini terus dibiarkan maka kemampuan proses mahasiswa tidak dapat diukur dan tidak dapat dilatih, sehingga akan mengurangi kualitas skill mahasiswa dalam kegiatan praktikum. Berdasarkan keadaan seperti diatas, maka perlu dikembangkan instrumen penilaian yang dapat mengukur keterampilan proses mahasiswa. Oleh karena itu, perlu dilakukan penelitian dengan judul "Standarisasi Instrumen Penilaian Keterampilan Proses Sains (KPS) pada Praktikum Mikrobiologi”.

\section{Metode}

Penelitian ini merupakan penelitian deskripsi kuantitatif, yang memfokuskan pada pembakuan instrumen penilaian dalam hal pembakuan intrumen yang selanjutnya akan diujicobakan pada mahasiswa semester IV Jurusan Pendidikan Biologi FMIPA yang memprogramkan matakuliah Mikrobiologi. Data yang diperoleh dianalisis secara deskriptif yang mengikuti langkah-langkah pembakuan instrumen.

Langkah-langkah atau prosedur dalam penelitian pembakuan instrumen penilaian ini diadaptasi dari Hidayati dan Listyani (TT) dapat diuraikan sebagai berikut:

1) Merumuskan Aspek-Aspek Keterampilan Proses Sains

Perumusan aspek-aspek keterampilan proses sains dilakukan agar diperoleh aspek-aspek keterampilan proses yang akan digunakan meliputi kemampuan observasi/pengamatan, kemampuan merumuskan hipotesis, kemampuan menggunakan alat dan pengukuran, mengkomunikasikan, melakukan klasifikasi dan menyimpulkan. 
2) Menyusun Indikator atau Butir-butir Keterampilan Proses Sains

Tahap ini dilaksanan untuk menyusun indikator dari masing-masing aspek keterampilan proses sains. Setiap aspek keterampilan proses sains ini terdiri dari 4 indikator.

\section{3) Melakukan Validasi Ahli oleh Pakar}

Suatu instrumen dikatakan memiliki validitas tinggi apabila instrumen tersebut dapat digunakan untuk mengukur apa yang seharusnya diukur (Sugiyono, 2011). Sebagai syarat untuk kevalidan suatu hasil penelitian maka instrumen yang digunakan dalam penelitian ini juga harus valid. Untuk itu dilakukan telaah pakar terhadap instrumen yang akan digunakan. Telaah pakar dilakukan dalam rangka validasi instrumen penilaian keterampilan proses sains. Validasi dilakukan oleh pakar Pendidikan Biologi dan Evaluasi Pendidikan, dengan tim validator I (ADM), Validator II (AMH) dan Validator III (LD). Teknik validasi ini dilakukan dengan meminta kesediaan validator memberikan koreksi terhadap komponen kelayakan isi maupun komponen kebahasaan. Teknik validasi digunakan untuk memperoleh data kevalidan intrumen berdasarkan penilaian para ahli. Data validasi diperoleh dengan cara memberikan lembar validasi kepada para ahli yang berperan sebagai validator. Saran yang diperoleh dari pakar dijadikan acuan untuk merevisi instrumen penilaian yang telah di bakukan.

\section{4) Merevisi Instrumen}

Hasil validasi selanjutnya direvisi sesuai saran dari validator meliputi aspek komponen isi dan aspek kebahasaan. Revisi yang dimaksud untuk memperbaiki instrumen penilaian yang dibuat berdasarkan koreksi dan saran dari validator yang selanjutnya akan diujicobakan di kelas.

\section{5) Melakukan Ujicoba}

Dalam tahap ujicoba ini dilakukan melalui dua tahap yaitu Ujicoba I dan Ujicoba II. Ujicoba I dilakukan untuk mendapatkan data awal untuk merevisi instrumen penilaian sehingga dapat disempurnakan serta mencari reliabilitas instrumen yang digunakan sehingga diperoleh instrumen yang baku. Instrumen yang baku merupakan instrumen yang teruji baik validitas maupun reliabilitasnya. Saran yang diperoleh dijadikan sebagai acuan untuk merevisi instrumen yang akan dikembangkan. Setelah dilakukan uji validasi dan reliabilitasnya oleh para ahli, instrumen yang telah direvisi di ujicobakan pada kelas terbatas (ujicoba I). Ujicoba I ini dilaksanakan pada mahasiswa kelas A dengan jumlah 10 orang. Hasil ujicoba I dikoreksi berdasarkan saran pembimbing dan pengamat, sehingga menghasilkan instrumen yang akan diujicobakan pada ujicoba II.

Ujicoba II dilaksanakan pada mahasiswa semester IV kelas A dengan jumlah 38 orang. Instrumen yang digunakan adalah instrumen yang telah melalui perbaikan pada ujicoba I. Mekanisme pelaksanaan ujicoba II pada dasarnya sama dengan ujicoba I, tetapi pelaksanaannya dilakukan pada kelas yang lebih luas dengan jumlah mahasiswa sebanyak 38 orang mahasiswa.

6) Penyempurnaan Instrumen Penilaian 
Penyempurnaan instrumen penelitian yang sudah melalui tahapan ujicoba I dan ujicoba II dilakukan sesuai dengan data yang diperoleh dari ujicoba I dan II yang akan menjadi hasil penelitian yang merupakan dasar penulisan tesis.

Uji validitas instrumen dalam penelitian ini bertujuan untuk mengetahui kelayakan instrumen dalam arti melihat validasi instrumen tersebut, dengan demikian peneliti mengetahuai apakah instrumen tersebut sudah memenuhi syarat yang diharapkan. Analisis data validasi intrumen penilaian dilakukan dengan cara mencari rata-rata tiap komponen dan tiap aspek dalam lembar validasi. Kemudian didapatkan rata-rata skor total dari keseluruhan aspek dari keseluruhan penilaian validator. Hasil penskoran dideskripsikan sebagai berikut:

$$
\begin{array}{ll}
4,50-5,00 & =\text { Sangat Sesuai } \\
3,50-4,49 & =\text { Sesuai } \\
2,50-3,49 & =\text { Cukup Sesuai } \\
1,50-2,49 & =\text { Kurang Sesuai } \\
0,00-1,49 & =\text { Tidak Sesuai }
\end{array}
$$

Setelah melakukan uji validasi, langkah selanjutnya adalah dengan melakukan pengukuran reliabilitas. Reliabilitas atau keandalan merupakan koefisien yang menunjukkan tingkat keajegan atau konsistensi hasil pengukuran suatu tes (Mardapi, 2012). Nilai reliabilitas dapat ditentukan dengan menentukan koefisisen reliabilitas dengan menggunakan formula Alpha.

\section{Hasil dan Pembahasan}

Penelitian ini telah dilaksanakan dengan tahapan pembakuan instrumen penilaian keterampilan proses sains. Intrumen tersebut divalidasi oleh validator yang kompeten dibidang evaluasi dan mikrobiologi. Aspek keterampilan proses sains yang dinilai adalah aspek butir keterampilan proses sains dan aspek bahasa, dimana masing-masing aspek terdiri dari beberapa indikator yakni observasi/pengamatan, merumuskan hipotesis, penggunaan alat dan pengukuran, mengkomunikasikan, mengklasifikasikan dan menyimpulkan. Berdasarkan hasil penelitian dan analisis data, diperoleh instrumen penilaian keterampilan proses sains pada praktikum mikrobiologi yang sudah memenuhi validitas dan reliabilitas yang diharapkan.

\begin{tabular}{|c|c|c|c|}
\hline $\begin{array}{l}\text { Uji } \\
\text { coba }\end{array}$ & $\begin{array}{c}\text { Komponen } \\
\text { yang direvisi }\end{array}$ & Jenis Revisi /masukan / saran dan koreksi & $\begin{array}{l}\text { Hasil } \\
\text { Revisi }\end{array}$ \\
\hline I & $\begin{array}{l}\text { 1) Komponen } \\
\text { Kelayakan } \\
\text { Isi }\end{array}$ & $\begin{array}{l}\text { a) Tidak perlu membuat instrumen penilaian } \\
\text { yang berbeda tiap kegiatan praktikum, } \\
\text { buat secara umum agar bisa di gunakan } \\
\text { pada semua kegiatan praktikum } \\
\text { Mikrobiologi }\end{array}$ & $\begin{array}{l}\text { Instrumen } \\
\text { penilaian } \\
\text { sudah } \\
\text { diperbaiki } \\
\text { sesuai }\end{array}$ \\
\hline & 2) Komponen & $\begin{array}{l}\text { b) Rentang skala penilaian diubah dari } 0-4 \\
\text { menjadi 1-5 dan keterangan skala } \\
\text { penilaiannya diperbaiki mengikuti rentang }\end{array}$ & $\begin{array}{l}\text { saran dan } \\
\text { koreksi } \\
\text { dari }\end{array}$ \\
\hline
\end{tabular}
Selanjutnya dilakukan ujicoba instrumen penilaian pada mahasiswa Jurusan Pendidikan Biologi FMIPA UNG yang memprogramkan matakuliah Mikrobiologi. Hasil penilaian dan hasil ujicoba instrumen penilaian adalah sebagai berikut:

Tabel 1. Hasil Revisi Instrumen Penilaian 


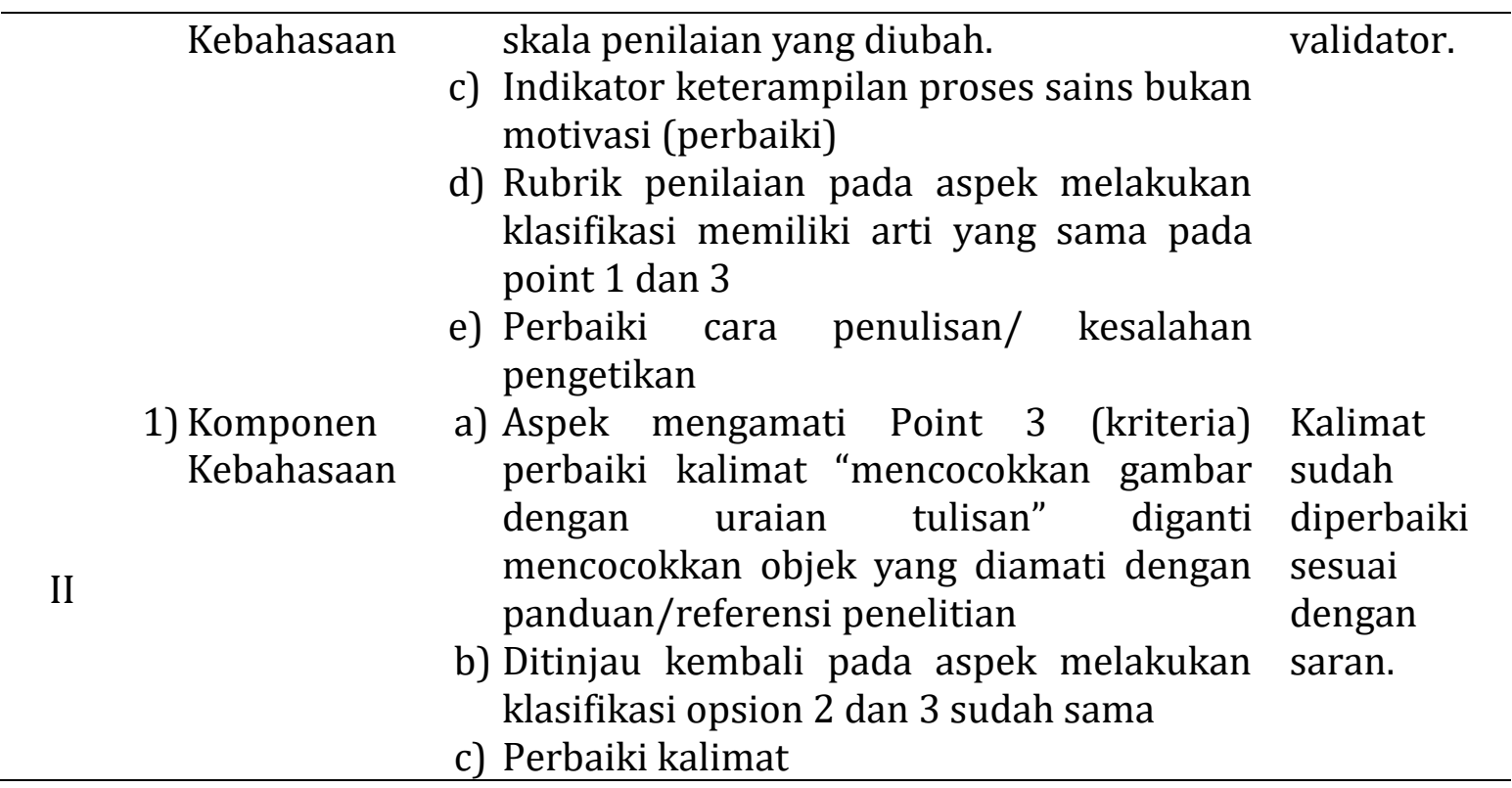

Tabel 2. Hasil Validasi Instrumen Penilaian Butir Keterampilan Proses Sains

\begin{tabular}{|c|c|c|c|}
\hline \multirow[b]{2}{*}{ No } & \multirow[b]{2}{*}{ Aspek yang Dinilai } & \multicolumn{2}{|c|}{ Penilaian Validator } \\
\hline & & $\begin{array}{c}\text { Rata-rata } \\
\text { Skor }\end{array}$ & Kategori \\
\hline $\mathbf{I}$ & Komponen Kelayakan Isi & & \\
\hline 1 & Melakukan Observasi/pengamatan & 4,7 & SS \\
\hline 2 & Merumuskan Hipotesis & 5 & SS \\
\hline 3 & Penggunaan Alat dan Pengukuran & 5 & SS \\
\hline 4 & Mengkomunikasikan & 5 & SS \\
\hline 5 & Melakukan Klasifikasi & 5 & SS \\
\hline 6 & Menyimpulkan & 5 & SS \\
\hline \multicolumn{2}{|c|}{ Rata-rata } & 4,95 & SS \\
\hline
\end{tabular}

Berdasarkan Tabel 2 diperoleh bahwa hasil penilaian terhadap instrumen penilaian keterampilan proses sains yang telah divalidasi oleh para pakar (validator) pada aspek komponen kelayakaan isi memiliki rata-rata skor keseluruhan adalah 4,95 termasuk kategori sangat setuju. Berdasarkan kriteria tersebut maka instrumen penilaian keterampilan proses sains pada praktikum mikrobiologi dinyatakan valid.

Tabel 3. Hasil Validasi Instrumen Penilaian Aspek Kebahasaan

\begin{tabular}{|c|c|c|c|}
\hline \multirow[b]{2}{*}{ No } & \multirow[b]{2}{*}{ Aspek yang Dinilai } & \multicolumn{2}{|c|}{ Penilaian Validator } \\
\hline & & $\begin{array}{c}\text { Rata-rata } \\
\text { Skor }\end{array}$ & Kategori \\
\hline I & Komponen Kebahasaan & & \\
\hline 1 & Rumusan kalimat komunikatif & 5 & SS \\
\hline \multirow[t]{2}{*}{2} & Kalimat menggunakan bahasa yang & & \\
\hline & baik dan benar & 4,7 & SS \\
\hline 3 & Kalimat tidak mengandung arti ganda & 5 & SS \\
\hline \multirow[t]{2}{*}{4} & Kesesuaian dengan kaidah bahasa & & \\
\hline & Indonesia yang benar & 4,7 & SS \\
\hline \multicolumn{2}{|c|}{ Rata-rata } & 4,85 & SS \\
\hline
\end{tabular}


Berdasarkan Tabel 3 diperoleh rata-rata skor untuk aspek kebahasaan adalah 4,85 termasuk kategori sangat sesuai. Hal ini terlihat pada hasil penilaian dari ketiga validator. Berdasrkan kriteria tersebut, maka validasi instruem penilaian pada aspek bahasa dinyatakan valid dengan kategori sangat setuju.

Tabel 4. Rekapitulasi Penilaian Keterampilan Proses Sains Mahasiswa Praktikum Mikrobiologi (Ujicoba I dan Ujicoba II)

\begin{tabular}{cccc}
\hline \multirow{2}{*}{ No } & Aspek yang dinilai & \multicolumn{2}{c}{ Tahap Ujicoba } \\
\cline { 3 - 4 } & & I & II \\
\hline 1 & Observasi/Pengamatan & 3,2 & 3,6 \\
2 & Merumuskan Hipotesis & 2,4 & 2,7 \\
3 & Penggunaan Alat \& & 3,1 & 3,6 \\
4 & Pengukuran & 3,4 & 3,8 \\
5 & Mengkomunikasikan & 2,8 & 3,1 \\
6 & Mengklasifikasikan & 3,1 & 3,4 \\
\hline & Menyimpulkan & 3,00 & 3,37 \\
\hline
\end{tabular}

Tabel 6. Reliabilitas Instrumen Penilaian Keterampilan Proses Sains dalam Kegiatan Praktikum (Ujicoba I dan Ujicoba II)

\begin{tabular}{cc}
\hline $\begin{array}{c}\text { Pengamatan Keterampilan Proses } \\
\text { Sains Mahasiswa }\end{array}$ & $\begin{array}{c}\text { Reliabilitas instrumen } \\
\text { Keterampilan proses sains } \\
\text { mahasiswa }\end{array}$ \\
\hline Ujicoba I & 0,81 \\
Ujicoba II & 0,82 \\
\hline Rata-rata & $\mathbf{0 , 8 2}$ \\
\hline
\end{tabular}

Berdasarkan hasil penelitian dan analisis data mengenai standarisasi instrumen penilaian keterampilan proses sains mahasiswa pada praktikum mikrobilogi dalam hal pembakuan instrumen menunjukkan bahwa instrumen penilaian tersebut telah memenuhi validitas dan reliabilitas yang diharapkan. Hal ini dapat dilihat dari hasil penilaian oleh validator pada aspek butir keterampilan proses dengan skor adalah 4,95 tergolong kategori sangat sesuai sehingga layak digunakan. Sedangkan pada aspek bahasa skor yang diperoleh adalah 4,85 tergolong kategori sangat sesuai. Dengan demikian instrumen penilaian keterampilan proses sains pada praktikum mikrobiologi dalam hal pembakuan telah memenuhi syarat utama sebagai instrumen yang baik.

Syarat utama instrumen yang baik adalah valid dan reliabel yang baik. Validitas menunjukkan sejauh mana alat pengukur itu mengukur apa yang ingin diukur. Sugiyono (2011) menyatakan bahwa instrumen yang valid adalah instrumen yang digunakan untuk mendapatkan data (mengukur) itu valid. Hal ini berarti bahwa validitas merupakan ciri instrumen yang terpenting. Instrumen yang valid dinamakan instrumen baku. Instrumen baku adalah instrumen yang diperoleh dari proses pengembangan instrumen melalui prosedur teoritis dan empiris dengan beberapa pengujian (Matondang, 2012).

Selain validitas, suatu instrumen yang baik harus memiliki reliabilitas yang tinggi. Hasil rekapitulasi reliabilitas instrumen penilaian keterampilan proses 
menunjukkan bahwa instrumen yang dibuat memiliki reliabilitas tinggi dengan perolehan skor rata-rata adalah 0,81 . Hal ini sesuai dengan pendapat Ratumanan \& Laurens (2011) bahwa instrumen pengamatan dikatakan baik apabila memiliki reliabilitas di atas 0,8. Dengan demikian, instrumen penilaian tersebut telah memenuhi syarat sebagai intrumen yang baik dalam mengukur ketrampilan proses sains mahasiswa.

Berdasarkan hasil ujicoba I dan ujicoba II, kemampuan mahasiswa dalam merumuskan hipotesis pada ujicoba I diperoleh skor rata-rata adalah 2,4 termasuk kategori cukup baik sedangkan pada ujicoba II diperoleh skor rata-rata adalah 3,6. Peningkatan terjadi karena mahasiswa sudah mampu merumuskan hipotesis sebelum melakukan praktikum. Kemampuan mahasiswa dalam kategori cukup baik tersebut karena belum semua mahasiswa dapat membuat hipotesis dengan benar. Adanya ketidakpahaman dalam membuat hipotesis tersebut, menjadi salah satu kendala mahasiswa dalam merumuskan hipotesis. Pada pertemuan pertama mahasiswa belum dapat merumuskan suatu hipotesis dengan benar dan pada pertemuan berikutnya mahasiswa sudah mulai dapat merumuskan hipotesis tetapi ada beberapa mahasiswa yang dapat merumuskan hipotesis tetapi setelah melakukan percobaan. Idealnya sebuah hipotesis dapat dirumuskan sebelum melakukan percobaan, hal ini sesuai dengan pendapat Nur (2011) tentang konsep merumuskan hipotesis yaitu suatu prediksi atau dugaan yang dapat diuji tentang bagaimana dan mengapa hal itu terjadi yang artinya bahwa hipotesis dibuat pada awal/sebelum percobaan dilakukan.

Kemampuan mahasiswa dalam mengkomunikasikan dan menggunakan alat/pengukuran termasuk dalam kategori baik pada ujicoba I dan ujicoba II termasuk kategori sangat baik. Hal ini terlihat jelas pada perolehan skor total dari setiap ujicoba, dimana mahasiwa sudah melakukan komunikasi yang baik antara anggota kelompok maupun kelompok lain. Sebagian besar mahasiswa mampu menggunakan alat dan melakukan pengukuran dengan baik tanpa bimbingan asisten. Namun beberapa mahasiswa tidak dapat mengoperasikan alat dengan baik. Hal ini terlihat pada saat praktikum pewarnaan gram mahasiswa tidak dapat menggunakan mikroskop dengan baik sehingga tidak dapat melakukan pengamatan terhadap kelompok bakteri gram positif dan gram negatif sehingga hal ini terjadi berulangulang dan perlu bantuan asisten. Selain itu ketersediaan fasilitas alat sangat menentukan keberlangsungan kegiatan praktikum. Terjadi peningkatan pada uji coba I dan ujicoba II, karena hal ini sangat bergantung pada perbedaan alat yang digunakan dalam tiap praktikum sehingga tingkat kompleksitas dan kesulitan tiap alat juga berbeda. Diketahui pada pertemuan pertama sampai empat alat yang digunakan adalah cawan petri, ose, dan tabung reaksi, pada pertemuan kelima sampai tujuh alat yang digunakan adalah mikroskop. Dapat disimpulkan bahwa keterampilan menggunakan alat tidak tergantung pada banyaknya atau jumlah kegiatan praktikum yang dilakukan tetapi sangat tergantung pada kerumitan alat yang digunakan dalam praktikum.

Kemampuan mahasiswa dalam mengklasifikasikan pada ujicoba I dan ujicoba II termasuk kategori baik. Walaupun masih ada sebagian mahasiswa yang masih kurang mampu dalam melakukan klasifikasi. Seperti yang ditemukan dilokasi penelitian yakni mahasiswa belum mampu membedakan bakteri gram negatif dan gram positif. Hal ini disebabkan kurangnnya kecermatan dan ketelitian dalam mengamati. Hal ini sesuai dengan pendapat Rustaman (2003) bahwa mengklasifikasikan didasarkan pada keterampilan observasi. Lebih lanjut Dimyati \& Moedjiono (2002) 
menambahkan bahwa mengklasifikasikan merupakan keterampilan proses untuk memilah berbagai objek dan berdasarkan sifat-sifat khusus, sehingga didapatkan golongan/kelompok sejenis dari objek yang dimaksud. Jika kegiatan mengamati tidak dilakukan dengan cermat dan hanya sekedar melihat saja, maka ketika mengklasifikasi hasil pengamatan mengalami kesulitan.

Keterampilan mahasiswa dalam membuat kesimpulan pada ujicoba I dan II termasuk dalam kategori baik dengan perolehan skor masing-masing adalah 3,1 dan 3,4 . Hal ini disebabkan oleh adanya data pengamatan yang mereka dapatkan setelah eksperimen yang dapat membatu mereka dalam membuat kesimpulan. Terjadinya peningkatan karena mahasiswa dapat membuat kesimpulan dengan baik.

Dalam kegiatan praktikum, keterampilan proses sains mahasiswa sangat diperlukan untuk tercapainya tujuan pembelajaran, karena mahasiswa tidak hanya sekedar memperoleh pengetahuan, akan tetapi menemukan fakta atau informasi itu sendiri. Hal ini sejalan dengan pendapat Nurmaya (2012) bahwa keterampilan proses sains sangat penting dilatihkan atau dikembangkan dalam pembelajaran, karena dengan memiliki keterampilan proses sains peserta didik akan lebih memahami apa yang dipelajari, karena peserta tidak hanya sekedar memperoleh pengetahuan, akan tetapi menemukan pengetahuan itu sendiri.

\section{Simpulan}

Berdasarkan hasil penelitian, dapat disimpulkan bahwa instrumen penilaian keterampilan proses sains yang telah dibuat memenuhi kriteria validitas dan reliabilitas. Ketika uji coba untuk melakukan pengukuran, instrumen dapat digunakan untuk mengukur KPS mahasiswa. Kegiatan praktikum selanjutnya dapat menggunakan instumen yang telah distandarisasi untuk mengukur keterampilan proses sains mahasiswa, khususnya pada mata kuliah mikrobiologi. Penelitian selanjutnya dapat menyusun instrumen KPS pada mata kuliah lainnya.

\section{Referensi}

Damopolii, I., Yohanita, A. M., Nurhidaya, N. \& Murtijani, M. (2018). Meningkatkan keterampilan proses sains dan hasil belajar siswa melalui pembelajaran berbasis inkuiri. J. Bioedukatika, 6(1), 22-30

Damopolii, I., Hasan, A., \& Kandowangko, N. (2015). Pengaruh strategi pembelajaran inkuiri bebas dimodifikasi dan kemampuan memecahkan masalah terhadap keterampilan proses sains mahasiswa pada praktikum fisiologi tumbuhan. Pancaran Pendidikan, 4(3), 191-200.

Devi, P. K. (2010). Keterampilan Proses dalam Pembelajaran IPA. Pusat pengembangan dan Pemberdayaan Pendidik dan Tenaga Kependidikan Ilmu Pengetahuan Alam (PPPPTK IPA).

Dimyati \& Moedjiono. (2002). Belajar dan Pembelajaran. Jakarta: Rineka Cipta

Hidayati \& Listyani. (2009). Pengembangan Instrumen Kemandirian Belajar Mahasiswa. FMIPA UNY, (Online), (http://www.google.co.id/ http $\% 3 \mathrm{~A} \% 2 \mathrm{~F} \% 2 \mathrm{Fstaff}$.uny.ac.id\%2Fsites\%2Fdefault $\% 2 \mathrm{Ffiles} \% 2 \mathrm{Fpenelitian} \% 2$ FKana\%2520Hidayati\%2C\%2520M.Pd.\%2FPengembangan\%2520Instrumen.p df.

Mardapi, D. (2012). Pengukuran, Penilaian \& Evaluasi Pendidikan. Yogyakarta: Nuha Medika 
Matondang, Z. (2012). Pengembangan Tes Kompetensi Guru SMK Bidang Keahlian Teknik Bangunan Di Medan. Disajikan pada Kegiatan Seminar Internasional di Makasar Mei 2012

Nur, M. (2011). Modul Keterampilan Proses Sains. Pusat Sains dan Matematika Sekolah. Universitas Negeri Surabaya.

Nurmaya, I. (2012). Penerapan Pembelajaran Berbasis praktikum untuk Meningkatkan Keterampilan proses sains dan penguasaan konsep. Universitas Pendidikan Indonesia. Repository.upi.edu

Pujiastuti, P. (2012). Pengembangan Model Pembelajaran Inkuiri Terbimbing Dipadu Kooperatif Teams Games Tournaments serta Pengaruhnya terhadap Keterampilan Proses dan Hasil Belajar IPA-Biologi pada Siswa Kelas V SD Berkemampuan Akademik Berbeda Di Kota Wates Kabupaten Kulonprogo. Disertasi. Universitas Negeri Malang

Ratumanan, T. G \& Laurens, T . (2011). Penilaian Hasil Belajar pada Tingkat Satuan Pendidikan, Edisi 2. Surabaya: Unesa University Press

Rustaman, N. (2003). Perencanaan dan Penelitian Praktikum di Perguruan Tinggi. Universitas Pendidikan Indonesia.

Semiawan, C., dkk. (1992). Pendekatan Keterampilan Proses, Bagaimana Mengaktifkan Siswa dalam Belajar. Jakarta: Gramedia

Sugiyono. (2011). Metode Penelitian Pendidikan Pendekatan Kuantitatif, Kualitatif dan R\&D. Bandung: Alfabeta

Suprananto \& Kusaeri. (2012). Pengukuran dan Penilaian Pendidikan. Yogyakarta: Graha Ilmu. 